\title{
Tinjauan Hukum tentang Anak yang Lahir di Luar Nikah Berdasarkan Hukum Waris Islam dan Hukum Perdata
}

\author{
Mahmudin Hasibuan \\ Sekolah Tinggi Agama Islam Barumun Raya Sibuhuan \\ e-mail : mahmudinhasibuan88@gmail.com
}

\begin{abstract}
Tujuan penelitian ini adalah untuk mengetahui bagaimana Tinjauan Hukum Tentang Anak Yang Lahir Di Luar Nikah Berdasarkan Hukum Waris Islam Dan Hukum Perdata. Jenis penelitian yang digunakan adalah penelitian kepustakaan (reseacr library) yakni penelaahan kepustakaan terhadap karya-karya ilmiah yang ada di pustaka yang berkaitan dengan Tinjauan Hukum Tentang Anak Yang Lahir Di Luar Nikah. Berdasarkan Hukum Waris Islam Dan Kitab Undang Undang Hukum Perdata Dalam Pembagian Waris. Adapun hasil penelitian ini adalah perlindungan anak memiliki makna fundamental, yaitu sebagai basis nilai dan paradigma untuk melakukan perubahan nasib anak. Dalam hukum perdata, perkawinan merupakan dasar terwujudnya pertalian keluarga dan hal ini melahirkan hak dan kewajiban diantara mereka yang termasuk di dalam lingkungan keluarga itu. Anak yang terlahir dari perkawinan yang sah dan secara otomatis memiliki hubungan keperdataan dengan ayahnya, hal ini disebutkan dalam Pasal 250 Kitab Undang-Undang Hukum Perdata (selanjutnya disebut KUH Perdata) menyatakan bahwa tiap-tiap anak yang dilahirkan atau ditumbuhkan sepanjang perkawinan, memperoleh si suami sebagai bapaknya.Kedudukan anak dalam hak kewarisan juga dijelaskan dalam KUHP perdata pada Pasal 852 yang menyebutkan bahwa "anak-anak atau sekalian keturunan mereka biar dilahirkan dari lain-lain perkawinan sekalipun, mewaris dari kedua orang tua, kakek, nenek atau semua keluarga sedarah mereka, selanjutnya dalam garis lurus ke atas dengan tiada perbedaan antara laki-laki dan perempuan dan tiada perbedaan berdasarkan kelahiran lebih dahulu.
\end{abstract}

\section{Key Words: Nafkah Istri; Perceraian Al-Qur'an}

\section{PENDAHULUAN}

Kehidupan manusia memiliki keterbatasan waktu.Apabila telah sampai pada batas akhir kehidupan dengan datangnya kematian, maka urusan keduniawian manusia tidak lantas berakhir. Kematian pada satu sisi memang telah mengakhirkan urusan duniawi orang yang meninggal tersebut, namun di sisi lain kematian itu juga akan menimbulkan dampak bagi orang-orang yang ditinggalkannya. Salah satu dampak tersebut adalah pembagian harta peninggalan orang yang meninggal di kalangan keluarga atau sering disebut dengan pembagian harta warisan.Pada hakikatnya kedudukan anak tidak hanya sebagai rahmat namun juga sebagai amanah dari Allah SWT.Dalam pandangan Islam, perlindungan anak memiliki makna fundamental, yaitu sebagai basis nilai dan paradigma untuk melakukan perubahan nasib anak.

Sejatinya nasab merupakan hak pertama yang diterima seorang anak setelah ia dilahirkan. Dengan tetapnya hak nasab, ia akan mendapatkan hakhaknya yang lain, meliputi hak 
keperdataan atau hak pemeliharaan dan nafkah, hak perwalian dan hak kewarisannya.Aturan tentang kewarisan ditetapkan Allah SWT.melaui firmanNya yang terdapat dalam Al-Qura'n. Pada dasarnya ketentuan tersebut berkenaan dengankewarisan jelas maksud dantujuannya.

Berbagai hal yang masih memerlukan penjelasan, baik yang bersifat menegaskan ataupun yang bersifat memerinci, disampaikan Rasulullah SAW. Melalui Hadisnya. Walaupun demikian, penerapannya masih menimbulkan wacana pemikiran dan pembahasan di kalangan pakar hukum Islam yang kemudian dirumuskan dalam bentuk ajaran yang bersifat normatif. Aturan tersebut menjadi pedoman bagi umat muslim dalam menyelesaikan permasalahan yang berkenaan dengan kewarisan (Amir Syarifuddin, 2012).

Ruang lingkup kajian hukum Islam terkait dengan waris sangat luas.Di antaranya meliputi orang-orang yang berhak menerima waris, bagian-bagian atau jumlah besaran waris, dan masih banyak lagi seperti tentang penambahan atau pengurangan bagian waris.Orang yang berhak menerima waris, dalam konteks hukum Islam, dibagi ke dalam tiga golongan yakni $d z u$ al -faraid, $d z u$ qarabat, mawali.

Ada tiga hal yang menyebabkan terjadinya saling mewarisi yakni: al qarabah atau pertalian darah, al-mus aharah atau hubungan perkawinan dan al-wala' atau memerdekakan hamba sahaya.Jika ketiga unsur di atas terpenuhi maka dapat terjadi hubungan saling mewarisi, kemudian memungkinkan dilakukan pembagian warisan dengan memperhatikan rukun pembagian warisan. Rukun pembagian warisan ada tiga, yaitu:

1. Al-Muwarist, yaitu orang yang diwarisi harta peninggalannya atau orang yang mewariskan hartanya.Syaratnya, al -muwarrith benar-benar telah meninggal dunia, apakah meninggal secara hakiki, secara yuridis (hukmi) atau secara taKdiri berdasarkan perkiraan.

2. Al-Warist atau ahli waris. Ahli waris adalah orang yang dinyatakan mempunyai hubungan kekerabatan baik karena hubungan darah, hubungan sebab perkawinan (semenda), atau karena akibat memerdekakan hamba sahaya. Syaratnya, pada saat meninggalnya almuwarris, ahli waris benar-benar dalam keadaan hidup. Termasuk dalam pengertian ini adalah, bayi yang masih berada dalam kandungan (alhamli). Meskipun masih berupa janin, apabila dapat dipastikan hidup, melalui gerakan (kontraksi) atau cara lainnya, maka bagi si janin tersebut berhak mendapatkan warisan. Untuk itu perlu diketahui batasan yang tegas mengenai batasan paling sedikit (batas minimal) dan atau paling lama (batas maksimal) usia kandungan. Ini dimaksudkan untuk mengetahui kepada siapa janin tersebut akan dinasabkan.

3. Al -Mawruth atau al -mirath, yaitu harta peninggalan si mati setelah dikurangi biaya perawatan jenazah, pelunasan utang, dan pelaksanaan wasia.

\section{MEDOTE}

Jenis penelitian yang digunakan adalah penelitian kepustakaan (reseacr library) yakni penelaahan kepustakaan terhadap karya-karya ilmiah yang ada di pustaka 
yang berkaitan dengan Tinjauan Hukum Tentang Anak Yang Lahir Di Luar Nikah. Berdasarkan Hukum Waris Islam Dan Kitab Undang Undang Hukum Perdata Dalam Pembagian Waris.

HASIL DAN PEMBAHASAN Anak Yang Lahir di Luar Nikah

Anak luar nikah adalah anak yang lahir dari hasil dari hubungan diluar nikah.Dalam Islam yang dipandang sebagai anak luar nikah adalah anak zina.Anak zina adalah anak yang lahir dari hasil hubungan tanpa pernikahan, biasa juga disebut dengan anak tidak sah karena dilahirkan diluar perkawinan yang sah.

Adapun perkawinan yang sah dan diakui di Indonesia ialah perkawinan yang dilakukan menurut hukum masingmasing agamanya dan kepercayaannya, dan dicatat menurut peraturan perundangundangan yang berlaku (pasal 2 (1) dan (2) UU No. 1 Tahun 1974). Dan pencatatan perkawinan dilakukan oleh pegawai pencatat nikah dari KUA untuk orang yang beragama islam.

Menurut UU No. 1 Tahun 1974 pasal 42, anak yang sah adalah anak yang dilahirkan dalam atau sebagai akibat perkawinan yang sah.Dan didalam KHI Anak yang sah adalah anak yang dilahirkan dalam atau akibat perkawinan yang sah dan merupakan hasil perbuatan suami istri yang sah diluar rahim dan dilahirkan oleh isteri tersebut (Huzaimah Tahido Yango, 2005).

\section{Tinjauan Hukum Islam Tentang \\ Kewarisan Anak di Luar Nikah}

Kata waris adalah dari bahasa Arab, dalam buku Ensiklopedi Islam disebutkan, kata,waris' berasal dari bahasa arab waritsa-yaritsu-wartsan atau irtsan/turats, yang berarti,mempusakai,
Waris adalah ketentuan tentang pembagian harta pusaka, orang yang berhak menerima waris, serta jumlahnya. Istilah waris sama dengan faraid, yang berarti, kadar atau,bagian. Kata Waris berarti orang yang berhak menerima pusaka (harta peninggalan) orang yang telah meninggal. Waris, yaitu harta kekayaan seaeorang, pada waktu ia meninggal maka akan beralih (berpindah) ke orang lain yang masih hidup, cara memperoleh harta waris dengan adanya pemindahan harta waris dari seseorang yang berhak kepada orang lain, jadi secara otomatis kepemilikan harta warisan akan berpindah pada orang lain dengan adanya kematian yang tak ditentukan siapa yang meninggal duluan. Dari mulai hak dan kewajiban seorang mayit itu akan berpindah secara otomatis dan di sinilah hukum waris Islam akan mengarahkan bagaimana harta itu akan sampai ke ahli warisnya (Azyumardi Azra, 2005).

Dalam al-Quran telah disinggung tentang warisan yang terdapat pada surat al-Nisâ' ayat 7. Dalam hal ini para fuqaha mendefinisikan pengertian waris dengan:Ilmu yang dengan dia dapat diketahui orang-orang yang mewarisi, orang-orang yang tidak mewarisi, kadar yang diterima. Oleh masing-masing ahli waris dengan cara pembagiannya (M. Fuad Abdul Baqy, t.th).

Waris dengan peraturan-peraturan yang mengatur perpindahan kekayaan seseorang yang meninggal dunia kepada ahli warisnya.Batasan tersebut merumuskan suatu asas dalam hukum waris, bahwa yang berpinadah di dalam pewarisan adalah kekayaan si pewaris (J.Satrio, 2016). 
Seperti yang sudah disebutkan di atas, harta yang ditinggalkan si mayit maka secara otomatis akan menjadi benda warisan, dan hukumwaris berlaku pada saat itu juga yang mana akan mengatur pembagian benda warisan tersebut. Anak luar nikah adalah anak yang lahir dari suatu perbuatan zina, yaitu hubungan kelamin antara laki-laki dengan perempuan yang tidak terikat dalam nikah yang sah meskipun ia lahir dalam suatu perkawinan yang sah, dengan laki-laki yang melakukan zina atau laki-laki lain (Komite Fakultas Syariah Universitas Al Azhar, 2009).

\section{Tinjauan Kitab Undang Undang} Hukum Perdata Tentang Kewarisan Anak di Luar Nikah

Hukum waris adalah hukum yang mengatur peralihan harta dari pewaris kepada ahli waris yang disebabkan karena pewaris telah meninggal. Di dalam hukum positif Indonesia terkait aturan yang mengatur hukum waris telat diatur sedemikian rupa di dalam Kitab Undang-Undang Hukum Perdata/ KUHPerdata (Burgerlijk Wetboek). Sebagaimana yang dikemukakan oleh Prof. Abdulkadir Muhammad, S.H. mengemukakan bahwa sistem yang dianut oleh KUHPerdata adalah sistem pewarisan individual bilateral. Artinya setiap ahli waris berhak menuntut pembagian harta warisan dan memperoleh bagian yang sama yang menjadi haknya, baik harta warisan dari ibunya maupun harta warisan dari ayahnya. Dengan demikian di dalam hukum waris haruslah ditentukan siapa ahli waris yang berhak menerima harta warisan dari pewaris. Hal ini telah diatur di dalam pasal 832 KUHPerdata yang berbunyi:
"Menurut undang-undang, yang berhak menjadi ahli waris ialah keluarga sedarah, baik yang sah menurut undangundang maupun yang di luar perkawinan, dan suami atau istri yang hidup terlama menurut peraturanperaturan berikut ini.

Bila keluarga sedarah dan suami atau isteri yang hidup terlama tidak ada, maka semua harta peninggalan menjadi milik negara, yang wajib melunasi utangutang orang yang meninggal tersebut, sejauh harga harta peninggalan mencukupi untuk itu"

Menurut Prof. Abdulkadir Muhammad, S.H. membagi ahli waris menjadi 3 sebagai berikut:

a. Ahli Waris asli (sesungguhnya) yang terdiri atas anak kandung dan istri/ suami pewaris. Dikatakan asli karena berasal dari perkawinan suami istri dan anak keturunannya termasuk anak luar kawin, ahli wasiat dan ahli waris pengganti.

b. Ahli waris karib yang dekat hubungan kekerabatannya dengan pewaris yang terdiri atas orang tua kandung, kakek/nenek, kakak/adik kandung, dan paman bibi (garis lurus ke atas dan menyamping)

c. Ahli waris lainnya jika urutan butir a dan b tidak ada, yaitu negara.

Sebelum adanya putusan Mahkamah Konstitusi Nomor: 46/PUUVIII/2010 terhadap hak warisan anak di luar kawin sering kali menjadi permasalahan. Hal ini disebabkan adanya pertentangan antara KUHPerdata dengan Undang-Undang No. 1 Tahun 1974 Tentang Perkawinan. Di dalam KUHPerdata pasal 862 menyatakan:

"Bila yang meninggal dunia meninggalkan anak-anak di luar kawin yang telah diakui secara sah menurut 
undang-undang, maka harta peninggalannya dibagi dengan cara yang ditentukan dalam pasal-pasal berikut (pasal selanjutnya dalam KUHPerdata red)."

Juncto pasal 280 yang menyatakan: "Dengan pengakuan terhadap anak di luar kawin, terlahirlah hubungan perdata antara anak itu dan bapak atau ibunya."

Berdasarkan pasal tersebut jelaslah bahwa di dalam KUHPerdata mengakui keberadaan anak di luar kawin untuk mendapatkan harta warisan dari pewaris sepanjang telah diakui secara sah menurut undang-undang.

Sedangkan di dalam UndangUndang No 1 Tahun 1974 Tentang Perkawinan hanya mengakui yang dimaksud dengan anak yang sah adalah anak yang dilahirkan dalam atau sebagai akibat perkawinan yang sah.Kemudian di dalam pasal 43 ayat (1) menyakan bahwa Anak yang dilahirkan di luar perkawinan hanya mempunyai hubungan perdata dengan ibunya dan keluarga ibunya.Sehingga apabila mengacu kepada Undang-Undang No. 1 Tahun 1974 Tentang Perkawinan, maka anak di luar kawin tidaklah berhak mendapatkan warisan dari ayah yang sebenarnya berdasarkan hubungan darah.Akan tetapi, seiring berjalannya waktu Mahkamah Konstitusi telah mengeluarkan putusan terkait kedudukan anak di luar kawin. Berdasarkan Putusan Mahkamah Konstitusi Nomor: 46/PUU-VIII/2010 tentang pengujian Undang-Undang No 1 Tahun 1974 Tentang Perkawinan terhadap UUD NRI 1945 yang mengabulkan sebagian permohonan yang diajukan oleh J. Aisyah Mochtar alias Machica binti H. Mochtar Ibrahim dan
Muhammad Iqbal Ramadhan bin Moerdiono. Dalam amar putusannya Mahkamah Konstitusi telah merubah makna pasal 43 ayat (1) Undang-Undang No 1 Tahun 1974 Tentang Perkawinan menjadi sebagai berikut:

"Anak yang dilahirkan di luar perkawinan mempunyai hubungan perdata dengan ibunya dan keluarga ibunya serta dengan laki-laki sebagai ayahnya yang dapat dibuktikan berdasarkan ilmu pengetahuan dan teknologi dan/atau alat bukti lain menurut hukum mempunyai hubungan darah, termasuk hubungan perdata dengan keluarga ayahnya"

Sehingga konsekuensi hukum yang ditimbulkan akibat Putusan Mahkamah Konstitusi tersebut, Undang-Undang No 1 Tahun 1974 Tentang Perkawinan tidak terdapat pertentangan lagi dengan aturan di dalam KUHPerdata dan telah mengakui kedudukan anak di luar kawin terhadap ayahnya dalam hal waris pada khususnya dan dalam hubungan hukum perdata lainnya pada umumnya sepanjang ayah dari anak tersebut dapat dibuktikan berdasarkan ilmu pengetahuan dan teknologi dan/atau alat bukti lain menurut hukum mempunyai hubungan darah, termasuk hubungan perdata dengan keluarga ayahnya. Alat bukti lain menurut hukum di sini sejalan dengan adanya pengakuan anak di luar kawin yang terdapat di dalam KUHPerdata. Akan tetapi perlulah dipahami syaratsyarat terhadap pengakuan anak di luar kawin berdasarkan KUHPerdata, diantaranya:

a. Pengakuan terhadap anak di luar kawin dapat dilakukan dengan suatu akta otentik (Pasal 281 KUHPerdata) 
b. Pengakuan anak di luar kawin dilakukan oleh orang yang cukup umur, yaitu telah mencapai sembilan belas tahun. Kecuali terhadap anak perempuan di bawah umur boleh melakukan pengakuan itu. (Pasal 282 KUHPerdata)

c. Anak yang bukan dilahirkan karena perzinaan atau penodaan darah (Pasal 283 KUHPerdata)

d. Pengakuan anak di luar kawin diterima selama mendapatkan persetujuan dari ibunya apabila ibunya masih hidup (Pasal 284 KUHPerdata)

Hak Pewarisan Anak di Luar KawinApabila kedudukan anak sudah jelas berdasarkan KUHPerdata dan Undang-Undang No 1 Tahun 1974 Tentang Perkawinan bahwa anak diluar kawin berhak mendapatkan warisan dari ayahnya, maka untuk bagian warisan anak di luar kawin menurut KUHPerdata adalah sebagai berikut:

a. Anak di luar kawin mendapatkan sepertiga bagian apabila yang meninggal itu meninggalkan keturunan sah menurut undangundang atau suami atau istri. (Pasal 863)

b. Anak di luar kawin mendapatkan separuh bagian apabila yang meninggal tidak meninggalkan keturunan, suami atau istri, tetapi meninggalkan keluarga sedarah dalam garis keturunan ke atas, atau saudara laki-laki dan perempuan. (Pasal 863)

c. Anak di luar kawin mendapatkan tiga perempat apabila yang meninggal hanya meninggalkan keluarga sedarah dalam derajat yang lebih jauh lagi. (Pasal 863)

d. Bagian anak di luar kawin yang dtelah diakui harus diberikan terlebih dahulu, kemudian sisanya dibagikan kepada para ahli waris yang sah. (Pasal 864)

e. Anak di luar kawin mewarisi seluruh harta pewaris apabila pewaris tidak meninggalkan ahli waris yang sah menurut undang-undang. (Pasal 865) (Benyamin Asri, 2008)

\section{KESIMPULAN}

Menurut hukum Islam seorang anak luar kawin hanya dinasabkan kepada ibunya, sehingga dengan demikian anak tersebut hanya dapat mewarisi dari ibunya dan keluarga ibunya dan begitu juga sebaliknya. Sedangkan terhadap ayah biologisnya ia tidak dapat mewarisi karena tidak ada hubungan nasab.

Menurut KUHPerdata terdapat kemungkinan anak luar kawin tidak mewarisi ibu dan ayahnya, ia baru dapat mewarisi setelah adanya pengakuan dari ibu dan ayah biologisnya. Pada dasarnya hukum Islam dan KUHPerdata samasama menyatakan bahwa anak luar kawin tidak dapat mewarisi ayah biologisnya. Perbedaan antara hukum Islam dengan KUHPerdata adalah pada hubungan anak luar kawin dengan ibunya, menurut hukum Islam anak luar kawin langsung dinasabkan kepada ibunya, sedangkan menurut KUHPerdata terdapat kemungkinan anak tersebut tidak mempunyai hubungan dengan ibunya, hubungan baru timbul setelah adanya pengakuan. Disarankan kepada seluruh umat, untuk melindungi harkat martabat diri dan menjaga keturunan tetap baik, agar selalu menjauhi diri dari perbuatan yang mendekati zina yang sehingga akan melahirkan anak luar kawin. Kepada orang tua dari anak luar kawin yang tunduk pada KUH Perdata agar tetap menjaga hak anak yang dibenihkan dengan melakukan pengakuan yang sah terhadap anak tersebut. Disarankan agar dibuatkan peraturan yang lebih detail yang mewajibkan orang tua dari anak luar kawin agar bertanggung jawab terhadap anaknya, serta dibuat aturan 
tentang kewarisan anak luar kaawin tersebut

\section{REFERENSI}

Afandi, Ali. Hukum Waris Hukum Keluarga Hukum Pembuktian. Jakarta: Rineka Cipta, 2004.

Mustaghfir, Aghis. Kewarisan Anak Zina Dalam Tinjauan Hukum Islam dan KUH $P$ erdata. Tesis, Program Studi Ahwal Syakhsiyyah. Program Pascasarjana, Institut Agama Islam Negeri Ponorogo, 2018.

Pitlo.Hukum Waris Menurut Kitab Undang-Undang Hukum Hukum Perdata Belanda. Jakarta: PT Intermasa, 2015.

Azra, Azyumardi. Ensiklopedi Islam. Jakarta: PT Ichtiar Baru Van Hove, 2005.

Basyir, Ahmad Azhar. Hukum Waris Islam. Yogyakarta: UII Press, 2014.

Asri, Benyamin. Dasar-Dasar Hukum Waris Barat Suatu Pembahasan Teoritis Dan Praktek. Bandung: Tarsito, 2008.

Saebani, Ahmad Beni. Metode Penelitian Hukum.Bandung: Pustaka Setia, 2009.

Ash Shiddieqy, Hasbi. Fikih Mawaris. Semarang: PT. Rizki Putra, 1987.

Yango, HuzaimahTahido. Masail Fikihiyah Kajian Hukum Islam Kontemporer. Bandung: Penerbit Angkasa, 2005.

Anshori, Ibnu. Perlindungan Anak Dalam Agama Islam. Jakarta: Komisi Perlindungan Anak Indonesia, 2006.

Soemitro, IrmaSetyowati. Aspek Hukum Perlindungan Anak. Jakarta: Bumi Aksara, 2015.

Satrio.Hukum Waris. Bandung: Penerbit Alumni, 2016.

Komite Fakultas Syariah Universitas Al Azhar, Hukum Waris. Jakarta: Senayan Abadi Publishing, 2009.

Kementrian Agama Republik Indonesia.Al-Qur'an dan Tafsirnya
Jilid 7. Jakarta: Widya Cahaya, 2011.

Maruzi, Muslich. Pokok-pokok Ilmu Waris. Semarang: Mujahidin, 1981.

Sembiring, Rosnidar. Hukum Keluarga Harta-Harta Benda dalam Perkawinan.Jakarta: PT. Raja Grafindo Persada, 2016.

Al Dimasyqi, MuhammadAbdurahman. Fikih Empat Madzhab. Bandung: Pustaka Ilmu, 2014.

Arikunto, Suharismi. Prosedur Penelitian Suatu Pendekatan Praktik. Jakarta: UIN Jakarta Press, 2002.

Simanjuntak.Hukum Perdata Indonesia.Jakarta: Kencana, 2015. 